\title{
Client adherence to nutritional obesity treatment in a school clinic
}

\author{
Amorim MMA ${ }^{1,2 *}$, Santana $\mathrm{NES}^{3}$, de Souza $\mathrm{AH}^{4}$ and Santiago $\mathrm{MC}^{1}$ \\ ${ }^{1}$ Nutritionist Teacher in University Center Una. Belo Horizonte, Brazil \\ ${ }^{2}$ Research Center for Studies on Migration and Intercultural Relations, Lisboa, Portugal \\ ${ }^{3}$ Academic Nutrition Course in University Center Una. Belo Horizonte, Brazil \\ ${ }^{4}$ Nutricionist Specialist in Geriatric Nutrition, Brazil
}

\begin{abstract}
Quantitative studies reveal that only $6.7 \%$ of clients submitted to nutritional therapy adhere to treatment. Evaluate the client adherence to nutritional treatment of obese clients attend in the Integrated Clinic for Health Care at the University Center Una, Belo Horizonte/MG, is the aim of this study. Sociodemographic and anthropometric data were collected from 232 medical records of clients with obesity. Women were predominant (82.32\%) and $65 \%$ of the clients sought weight loss. Obesity was higher in women aged 40-59 years (41.8\%) and 30-39 years (27.2\%). In men the prevalence was in the 19-29 years (53.6\%). Women between 30-39 years and men between 60-69 years presented the highest average weight loss and highest number of consultations. Factors such as schooling did not show interference with adherence to treatment. It was concluded that clients who adhere to the nutritional treatment and return to the consultations reach their objectives.
\end{abstract}

\section{Introduction}

Obesity is a multifactor disease characterized by the excessive body fat accumulation as a result of the high energy intake and low energy expenditure. This disease has been affecting a considerable part of the population, in all age groups and increasing the costs of public health [1].

In 2016 in Brazil, more than half of population was overweight and $18.9 \%$ of Brazilians were obese. The prevalence of overweight is higher in males and the age and the lower level of schooling contribute to the increase of this indicator. On the other hand, obesity has a higher prevalence in women (19.6\%) than men (18.1\%), according to a study realized in 27 Brazilian capitals [2]. It is estimated that in the years $2020-2025$ about $50 \%$ of the world population will be obese [1]

The hypocaloric diet associated to exercises constituted the main therapy for weight loss and the risk of developing chronic noncommunicable diseases (CNCD) in people with obesity [3]. However, the change in eating habits trough nutritional intervention is one of the intervening factors of adherence to treatment [4].

Nutritional intervention aims to the prevention of diseases, promotion and protection of a healthy life leading the subject to a general well-being [5]. Nutritional therapy in CNCDs has a prominent place, requiring even more commitment from the patient. It is estimated that about $50 \%$ or more of these clients do not follow the treatment properly [6]. The result of this is the number of deaths due to DNCD that reaches 74\%, representing in Brazil the largest cause of death. A Strategic Action Plan for Coping with CNCDs was launched in 2011 to reduce the premature mortality rate by $2 \%$ per year by 2022 . Among the actions, the first one is stopping the growth of obesity in adult population until 2019, through intersectoral health and food and nutritional security policies [2]. However it is fundamental that the client adhere or have an active participation in the treatment.

The concept of adherence can be understood as a set of actions whose the main goal is the following of the guidelines, including frequency of consultations, adherence to care such as medication and non-drug therapy, client behavior and behavioral changes, as well as guidelines such as cessation of smoking, incentive to practice physical activity and reduction of alcohol consumption [4].

The low adherence to treatment is associated to greater risk of morbidity and mortality, besides the frustration of health professionals, as it compromises the achievement of the goals sets leading to unnecessary readjustment of therapy and increased costs with hospitalization and treatment of complications [6]. Quantitative studies show that only $6.7 \%$ of clients submitted to nutritional therapy adhere to treatment [4].

In this context, research that investigates adherence to nutritional therapy may provide subsidies to devise adequate strategies that allow an individualized approach and a more specific intervention. In this sense, this study aims to evaluate the adherence to the nutritional treatment of clients with obesity treated at the Integrated Clinic for Health Care at the University Center Una, Belo Horizonte/MG.

\section{Materials and methods}

This cross-sectional study was performed through the collection of data from 2054 medical records of the clients attended at the Integrated Clinic for Health Care at the University Center Una, Guajajaras Campus, Belo Horizonte/MG, at the second half of 2017. Were considered as inclusion criteria clients with obesity and who attended at least three consultations and as exclusion: records with incomplete data.

*Correspondence to: Maria Marta Amancio Amorim, Nutritionist Teacher in University Center Una. Belo Horizonte, Brazil, E-mail: martamorim@hotmail.com

Key words: obesity, nutritional treatment, adherence to treatment

Received: September 11, 2018; Accepted: September 28, 2018; Published: October 02, 2018 
The accomplishment of this study was approved by the Ethics and Research Committee of University Center UNA, under CAAE opinion 67531517.2.0000.5098. All information was collected by the author of the research in the Clinic with the authorization of the responsible teachers.

Concerning sociodemographic data were collected gender, age, schooling, reason that led the client to seek the attendance and number of consultations. The information about food preferences were also collected from the records.

As for the anthropometric data, weight and height were collected, following anthropometric standards [7]. These data were used to calculate the body mass index (BMI) from the formula weight $(\mathrm{kg})$ divided by height $(\mathrm{m} 2)$, and classified as eutrophic $\left(18.5 \mathrm{~kg} / \mathrm{m}^{2}\right.$ at 24.9 $\mathrm{kg} / \mathrm{m}^{2}$ ), overweight $\left(25\right.$ to $27 \mathrm{~kg} / \mathrm{m}^{2}$ ) and obesity (values over $30 \mathrm{~kg} /$ $\mathrm{m}^{2}$ ) for adults and eutrophic (22 to $27 \mathrm{~kg} / \mathrm{m}^{2}$ ), overweight (27 to 32 $\mathrm{kg} / \mathrm{m}^{2}$ ) and obesity (values above $32 \mathrm{~kg} / \mathrm{m}^{2}$ ) for the elderly according to the World Health Organization [8,9]. The BMI data were compared between the first and last care.

The four skin folds, triceps (TSF), biceps (BSF), supra iliac (SISF) and subscapular (SESF) were performed following the appropriate standards [10]. The percentage of fat was defined after summation of the four skin folds following the protocols [11]. Fat percentage data were presented according to gender and age group.

The data from BMI, fat percentage, number of consultation and weight loss were correlated with schooling.

The quantitative data were presented by means of the absolute and relative frequency and described by mean and standard deviation. For tabulation of the data, the software Microsoft Excel, version 2016 was used and Test $t$ was the statistical analysis used to evaluate if there was a significant difference $(p<0.05)$ between the values of initial and final BMI, performed using Assistant software.

\section{Results}

Of the 2054 medical records analyzed in the second half of 2017, $232(11.29 \%)$ met the inclusion criteria. Of these, 41 (17.67\%) were males and $191(82.32 \%)$ were females.

The average age of clients was $39.4 \pm 13.4$ years varying between 19 and 80 years. For women was $40.5 \pm 13.39$ years and for men was $34.9 \pm 13.46$ years.

As to the level of schooling, most of clients had a high school diploma ( $27.58 \%, \mathrm{n}=64)$, followed by an incomplete superior $(15.51 \%$, $\mathrm{n}=36)$, complete superior $(13.8 \%, \mathrm{n}=32)$, incomplete elementary school $(8.2 \%, \mathrm{n}=19)$, complete primary school $(6.9 \%, \mathrm{n}=16)$, incomplete high school $(4.75 \%, \mathrm{n}=11)$, functional illiterate $(86 \%, \mathrm{n}=2)$ and postgraduate $(2.15 \%, n=5)$. The others $(20.25 \%, n=47)$ did not respond.

When asked about the reason for seeking care at the clinic, 151 (65\%) clients reported their desire to lose weight, 40 (17.24\%) sought food re-education and the other (41) specific treatment for some disease.

Figure 1 shows the result of dietary preferences reported by customers when asked what foods they do not would like to be removed from the diet. The sources of carbohydrate were the most cited, such as rice, pasta and breads, followed by meats, vegetables, sweets and soft drinks.

Table 1 shows the anthropometric evaluation according to the level of schooling of clients with obesity attended at the Integrated Clinic for
Health Care at the University Center Una, Belo Horizonte, 2018. It was noticed that the higher the educational level, the lower the percentage of fat and BMI. However, weight loss was higher in individuals with a high school diploma when compared to postgraduates.

In Table 2 is presented the initial and final BMI, fat percentage, number of consultations and average weight loss for females and males client with obesity attended at Integrated Clinic for Health Care at the University Center Una, Belo Horizonte, 2018. Obesity has shown most prevalent in women with ages between 40-59 and 30-39 years old, representing $41.8 \%(\mathrm{n}=80)$ and $27.2 \%(\mathrm{n}=52)$ respectively. In males, the

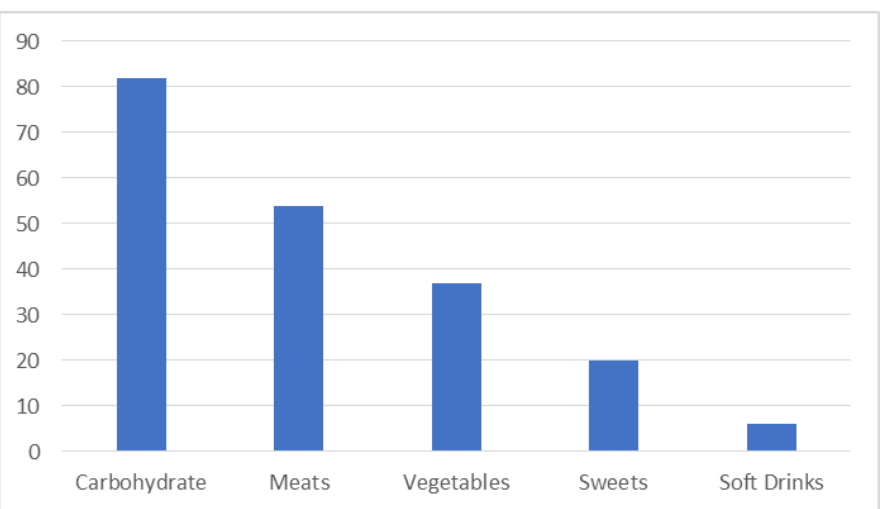

Figure 1. Food preferences of clients attended at the integrated health care clinic of university centre una, belo horizonte, 2018

Table 1. Schooling associated to the percentage of fat, body mass index, weight loss of obese clients attended by the Integrated Clinic for Health Care at the University Center Una, Belo Horizonte, 2018

\begin{tabular}{|c|c|c|c|c|}
\hline Schooling & $\mathbf{N}$ & Fat initial \% & $\begin{array}{c}\text { BMI initial } \\
\left(\mathbf{k g} / \mathbf{m}^{2}\right)\end{array}$ & $\begin{array}{c}\text { Weight loss } \\
(\mathbf{K g})\end{array}$ \\
\hline Illiterate & 2 & 38.9 & 34.56 & 0.7 \\
\hline First degree completed & 16 & 42.5 & 35.98 & 1.75 \\
\hline First degree incomplete & 19 & 40.8 & 34.55 & 1.52 \\
\hline Second degree completed & 64 & 38.63 & 34.63 & 2.35 \\
\hline Second degree incomplete & 11 & 41.24 & 34.08 & 1.75 \\
\hline Graduated & 32 & 35.96 & 34.72 & 1.8 \\
\hline Incomplete graduation & 36 & 36.09 & 35.50 & 2.16 \\
\hline Postgraduate & 5 & 33.45 & 33.72 & 0.84 \\
\hline Did not answer & 47 & 26.8 & 35.7 & 1.7 \\
\hline Total & 232 & & & \\
\hline
\end{tabular}

Table 2. Initial and final body mass index, percentage of fat at the first visit, number of visits and average weight loss of patients attended at Integrated Clinic for Health Care at the University Center Una, Belo Horizonte, 2018

\begin{tabular}{|c|c|c|c|c|c|c|}
\hline $\begin{array}{c}\text { Sex } \\
\text { Age range }\end{array}$ & $\mathbf{N}$ & $\begin{array}{c}\text { BMI } \\
\text { initial } \\
\left(\mathrm{kg} / \mathrm{m}^{2}\right)\end{array}$ & $\begin{array}{c}\text { BMI } \\
\text { final } \\
\left(\mathrm{kg} / \mathrm{m}^{2}\right)\end{array}$ & $\begin{array}{c}\text { Fat } \\
\%\end{array}$ & $\begin{array}{c}\text { Number of } \\
\text { visits }\end{array}$ & $\begin{array}{c}\text { Average } \\
\text { weight loss } \\
\text { (kg) }\end{array}$ \\
\hline \multicolumn{7}{|l|}{ Women } \\
\hline $19-29$ years & 43 & 34.60 & 33.90 & 37.05 & 3.97 & 2.12 \\
\hline $30-39$ years & 52 & 35.40 & 34.40 & 39.10 & 5.07 & 2.61 \\
\hline $40-59$ years & 80 & 35.70 & 34.90 & 43.80 & 4.50 & 2.08 \\
\hline $60-69$ years & 11 & 33.50 & 33.50 & 44.00 & 4.70 & 0.19 \\
\hline $70-80$ years & 5 & 33.20 & 33.00 & 40.00 & 3.50 & 0.40 \\
\hline Total & 191 & 35.20 & 34.40 & 40.89 & 4.5 & 2.06 \\
\hline \multicolumn{7}{|l|}{ Men } \\
\hline $19-29$ years & 22 & 35.70 & 35.38 & 25.85 & 3.80 & 1.27 \\
\hline $30-39$ years & 10 & 33.20 & 33.10 & 32.40 & 3.70 & 0.44 \\
\hline $40-59$ years & 5 & 36.20 & 35.70 & 36.80 & 3.75 & 1.68 \\
\hline $60-69$ years & 4 & 35.50 & 34.30 & 30.60 & 7.00 & 3.46 \\
\hline Total & 41 & 35.19 & 34.76 & 27.32 & 4.2 & 1.40 \\
\hline
\end{tabular}


age group between 19-29 years is where the largest number of clients with obesity is found, with $53.6 \%(n=22)$ of the cases.

The women presented the highest average percentages of fat at the first visit, 40.89 \pm 5.69 when compared with the men, 27.32 \pm 9.52 . In both genders there is an increase in fat percentage with age, reducing again after 60-69 years for men and 70-80 for women.

Weight loss during nutritional monitoring was higher in men aged 60-69 years $(\mathrm{p}=0.5)$ followed by women aged 30-39 $(\mathrm{p}=0.8)$, consequently the reduction in BMI was greater in these cases, not being significant. These were also the groups that most attended the consultations with an average of 7 and 5 appointments performed, respectively, showing that the client's frequency plays an important role in achieving the results for weight loss.

\section{Discussion}

The present study has shown a higher number of women (82.33\%) attended at the School Clinic. Similar results were found by Souza and Nunes [12], when $71.7 \%$ were women among obese clients attended in a nutritional clinic in Ribeirão Preto. There is an association of care and prevention related to the females, since men tend not to want to expose themselves and look for healing practices [12].

Related to age range, there was predominance of adults between 40 and 59 years for women and 19 and 29 years for men attended at the Clinic. According to Calejjon and Paternez [5] elderly people who have already been affected by some disease seek to increase the years of survival and seek more for consultations. Young people do not care about the emergence of comorbidities and seek nutritional care for aesthetic issues and the desire to feel good about themselves.

In the present study, the large number of individuals who completed the high school and who sought care are students from the University Center Una, where the Integrated Clinic is located, as well as a study conducted in Teresina by Fernandes et al. (2016). The academic level is a factor that, according to Souza and Nunes [12] directly influence adherence, because the lower the level of education, the more difficult is the understanding of therapy, leading to treatment abandonment.

The biggest reason for seeking to nutritional care at the School Clinic was the weight loss. Similar results were found by Leal [13] were $62 \%$ of clients aimed weight loss. At the Niquini, Navarro and Bessa [14] study, clients with obesity reported that the difficulty to perform daily activities, social prejudice and mirror image are the main causes of the demand for treatment.

In the present study, carbohydrates sources were the main foods reported as preferred by clients. Fernandes et al. [15], research on food consumption and overweight in adults found carbohydrate intake higher than recommended in $36 \%$ of the study population.

The change in eating behavior is considered the main intervening factor in adherence to the treatment of CNCD. Niquini, Navarro and Bessa [14] pointed out in their study that anxiety and the relationship with food on free demand and time are the main complaints when asked about changes in eating habits. Calejjon and Paternez [5] add to clients' difficulty in following the food plan with balanced amounts of nutrients at events and during weekends. Patients with obesity and other CNCDs represent the highest percentage of non-adherents to treatment, usually because they do not accept or do not see obesity as a disease [14].

In the present study, women, mainly between 40-59 years old represented the highest percentage of clients with obesity attended by the clinic. Corroborating these results, the System of Surveillance of Risk Factors and Protection for Chronic Diseases by Telephone Inquiry (Vigitel) also found a higher prevalence of obesity in women (19.6\%) of the 26 Brazilian capitals and the Federal District [2]. However, Fernandes et al. [15] in a study with 80 adults attending a Clinical School of a university in Teresina found a higher prevalence of obesity among men $(n=46)$, showing that the disease reaches both sexes.

In males, the age group between 19-29 years had the highest BMI, but this is not a safe parameter of comparison, considering that this indicator considers only the variables weight and height. In men, BMI can be influenced by lean mass, which in young adults has a good representation of body weight, decreasing according to the advancement of age, which may have contributed to the difference between the BMI of adults and the elderly [10].

By relating the number of consultations with the results obtained, we can see that the groups that attended the most consultations had the best results when compared to the weight and initial and final BMI. Pereira et al. [16] in the evaluation of obese clients attended at a clinical school verified that of the 9 volunteers who returned to the service, 8 reached the goal of weight loss and dietary reeducation.

In Chile, 128 women submitted to physical activity sessions, a workshop with nutritionist and psychologist presented significant results of weight, BMI and waist circumference reduction. Women had greater adherence and participation in physical activity and it was the group that had the greatest weight reduction [17].

Another study realized with 116 individuals with overweight and obesity participants of the Food Education Program of Ribeirão Preto show that $50 \%$ of the participants were adhered to the program, and the obese grades II and III represent the highest percentages [18].

Chronic treatments have generally lower adherence, since therapies require great commitment from the client, and this must be constant [19], however clinical studies reveal up to $80 \%$ of treatment withdrawal [20]. According to Niquini, Navarro and Bessa [14] "the variable relationship between patient and prescriber affects adherence to treatment so that when this relationship provides emotional support, partnership and patient confidence the therapeutic adherence is greater". The health professional has an educative and motivational role in the treatment of obesity, being extremely important the stimulus for behavioral changes for clients submitted to non-drug therapies.

\section{Conclusion}

The presence of the client in the office has been shown to be fundamental for the improvement of the anthropometric profile of people with obesity, however adherence to the treatment is influenced by numerous factors that still need to be studied because the data are scarce in the literature. Health professionals need to perform educational, encouraging and assistance role, facilitating the professional-patient relationship and therefore getting better results.

\section{References}

1. Palmeira CS, Garrigo LMM, Santana P (2016) Fatores intervenientes na adesão ao tratamento da obesidade [Participant factors in adherence to the treatment of obesity] Ciência y Enfermeria 1: 11-22.

2. Ministério da Saúde, Vigitel Brasil (2016) Vigilância de fatores de risco e proteção para doenças crônicas por inquérito telefônico: estimativas sobre frequência e distribuição sociodemográfica de fatores de risco e proteção para doenças crônicas nas capitais dos 26 estados brasileiros e no Distrito Federal em 2016 [Vigitel Brasil 2016: surveillance of risk factors and protection for chronic diseases by telephone survey: estimates of frequency and sociodemographic distribution of risk factors and protection for chronic 
diseases in the capitals of the 26 Brazilian states and in the Federal District in 2016]. Ministério da Saúde, Secretaria de Vigilância em Saúde, Departamento de Vigilância de Doenças e Agravos não Transmissíveis e Promoção da Saúde. Brasília.

3. Gonçalves ISA, Ferreira NTMY, Reis PVS, Pena GG (2015) Fatores intervenientes no seguimento do tratamento nutricional para redução de peso em mulheres atendidas em uma Unidade Básica de Saúde do Brasil Intervening factors in the follow-up of nutritional treatment for weight reduction in women attended at a Basic Health Unit in Brazil. Cuidarte 6: 914-922.

4. Souza ACB, Oliveira JED, Caritá EC, Almeida CAN (2017) Perfil dos pacientes obesos no primeiro atendimento em Ambulatório de Nutrologia Municipal de Ribeirão Preto (SP) Profile of obese patients in the first service at the Municipal Nutrition Clinic of Ribeirão Preto (SP). Medicina 50: 207-215.

5. Callejon KS, Paternez ACAC (2008) Adesão ao tratamento nutricional por pacientes atendidos na clínica de nutrição docente assistencial da universidade municipal de São Caetano do Sul Adherence to nutritional treatment by patients attended at the nutrition teaching clinic of the São Caetano do Sul municipal university. Revista Brasileira de Ciências da Saúde 17: 3-8.

6. Estrela CA, Alves ACC, Gomes TT, Isasaki M (2017) Adesão às orientações nutricionais: uma revisão de literatura [Adherence to nutritional guidelines: a literature review]. Demetra 12: 249-274

7. Instituto Brasileiro De Geografia E Estatística (2013) Manual de antropometria Anthropometry Manual. Rio de Janeiro: IBGE, pp: 7-10.

8. Organización Mundial de la Salud (1995) El estado físico: uso e interpretación de la antropometria-Physical state: use and interpretation of anthropometry. Genebra: OMS 452-854.

9. Lipschitz DA (1994) Screening for nutritional status in the elderly. Prim Care 21: 5567. [Crossref]

10. Rossi L, Caruso L, Galante AP (2008) Avaliação Nutricional: novas perspectivas Nutritional assessment: new perspectives. $1^{\text {a }}$ edição. Editora Roca: São Paulo.

11. Durnin JVA, Worsley J (1974) Body fat assessed from total body density and its estimation from skinfold thickness: measurements on 481 men and women aged from 16 to 72 years. BrJ Nutr 32: 77 .
12. Sousa AEC, Nunes RM (2014) Avaliação da adesão terapêutica nutricional e sua relação com os modelos de mudança do comportamento alimentar Evaluation of nutritional therapeutic adherence and its relation with the models of food behavior change. $H U$ Revista 40: 221-229.

13. Leal FS (2012) Tratamento da obesidade: investigando o abandono e seus aspecto motivacionais [Obesity treatment: investigating abandonment and its motivationa aspects]. Dissertação (Mestrado em Enfermagem em Saúde Pública) Ribeirão Preto, USP, pp: 120

14. Niquini C, Navarro F, Bessa F (2012) Fatores associados à adesão e não adesão do tratamento não farmacológico em usuários com obesidade assistidos pelo programa saúde da família, Complexo do Alemão/RJ [Factors associated with adherence and non-adherence of non-pharmacological treatment in obese users assisted by the family health program, Complexo do Alemão/RJ]. Revista Brasileira de Obesidade, Nutrição e Emagrecimento 6: 46- 57.

15. Fernandes ACCF, Martins MCC, Santos RS, Tapety FI (2016) Excesso de peso consumo alimentar de adultos [Excess weight and adult food intake]. Rev Enferm UFPE 10: 1360-1367.

16. Pereira SEA, Capelli JCS, Moraes VM, Cardoso FT, Almeida FT, et al. (2009) Avaliação da adesão ao tratamento nutricional em uma Clínica Escola de uma Instituição de Ensino Superior [Evaluation of adherence to nutritional treatment in a Clinic School of a University]. Augustus 3: 1-11.

17. Bianchini JA, Hintze LJ, Bevilaqua C, Dell Agnolo, Junior NN (2012) Tratamento da Obesidade: Revisão de artigos sobre intervenções multiprofissionais no contexto brasileiro [Treatment of Obesity: Review of articles on multiprofessional interventions in the Brazilian context]. Arq Cien e Saúde 19: 9-15.

18. Bueno JM, Leal FS, Sáquy LPL, Santos CB, Ribeiro RPD (2011) Educação alimenta na obesidade: adesão e resultados antropométricos [Food education in obesity: adherence and anthropometric results]. Rev Nutr 24: 575-584.

19. Busnello FM, Bodanese LC, Pellanda LC, Santos ZEA (2011) Intervenção nutricional e o impacto da adesão ao tratamento em pacientes com síndrome metabólica [Nutritional intervention and the impact of adherence to treatment in patients with metabolic syndrome]. Arq Bras Cardiol 97:217-224

20. Inelmen EM, Toffanello ED, Enzi G, Gasparini G, Miotto F, et al. (2005) Predictors of drop-out in overweight and obese outpatients. Int J Obes (Lond) 29: 122-128. [Crossref]

Copyright: ${ }^{0} 2018$ Amorim MMA. This is an open-access article distributed under the terms of the Creative Commons Attribution License, which permits unrestricted use, distribution, and reproduction in any medium, provided the original author and source are credited. 